\title{
Regional weather and climates of the British Isles - Part 6: Ireland
}

\section{John Sweeney \\ National University of Ireland, Maynooth}

\section{Introduction}

On 4 June 1944, the lighthouse keeper at Blacksod Bay on the far northwest of County Mayo relayed his usual weather observations to Dublin and on to London. On receiving the report from Blacksod, the Allied commanders decided to postpone for a day Operation Overlord that was to launch the invasion of German-occupied western Europe: a wise move since the Force 7 winds and heavy rain experienced in the Channel the next day could have seriously compromised the success of the operation. Sitting astride the main storm tracks, Ireland has always provided an early warning system, particularly for Britain, of forthcoming extreme events originating over the Atlantic, as well as a shield which lessens their severity.

Ireland possesses a rich and varied climate mosaic, a product of its distinctive topography and geography, which interact with airstreams to produce a complex spatial arrangement of climates not often appreciated beyond its shores. In Victorian times the geomorphology of Ireland was taught by an analogy to an apple pie - the hard crusty bits around the edges enclosing a soft centre. This geological legacy of hard Caledonian and Armorican rocks around the perimeter and soft Carboniferous limestones in the centre creates an unusual topographic arrangement (Figure 1). In the west, with only a few breaks in the mountainous edge at Sligo Bay, Galway Bay and the Shannon Estuary that allow easier access for maritime air masses, there are some surprisingly sheltered pockets. The south and north coasts also have their mountain bulwarks in the Cork-Kerry and Donegal mountains and some protection is even afforded to the east coast by the Antrim Plateau and the Wicklow Mountains. A coast-versus-interior geography is, therefore, the chief characteristic of the Irish climate, so that the climate of the Central Plain has more in common with lowland England than with its Celtic neighbours of Wales and 20 Scotland.

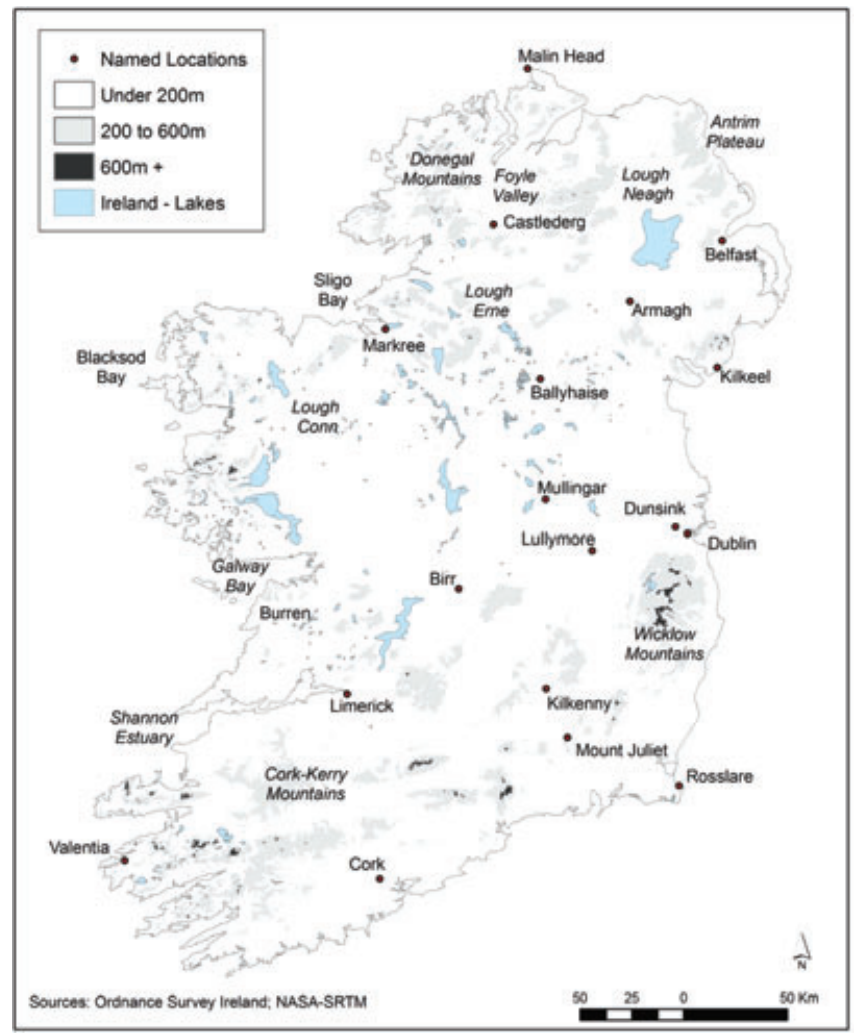

Figure 1. Locations named in the text.

\section{The legacy of past weather observations}

The practice of keeping weather diaries became established in many European countries from the late fifteenth century, whilst some fragmentary records exist from up to three centuries earlier. The annals written in Irish monasteries, however, provide the oldest written records of the continent. The earliest documentary reference to a meteorological event in Europe is probably a reference in the Annals of the Four Masters to Lough Conn 'erupting', allegedly in 2668 BC (Figure 2). A long tradition of recording extreme events through the generations exists. Early weather diaries tended to be fragmentary, such as that of William Molyneux and St John Ashe from 1684 to 1686 (which included barometric readings). Temperature records emerged in 1721-1722 from George Rye in Cork, while Thomas Neve on the shores of Lough Neagh devised a raingauge that he used from 1711 to 1725 , augmented by a barometer and thermometer in later years. Among the most impressive was Richard Kirwan's record of 1787-1808 from Cavendish Row, Dublin, which involved a pressure-plate anemometer he designed himself. One of the outstanding scientists of his time, Kirwan wrote prolifically (one of his papers in the Transactions of the Royal Irish Academy stretched to 229 pages) and he was particularly vociferous in calling for standardisation of measurements and decimalisation of scales (Dixon, 1969).

By the end of the eighteenth century, organised weather-data collection was part of the remit of astronomical observatories. Dunsink (1788), Armagh (1790), Markree (1824) and Birr (1845) are the best known, and indeed Armagh has unbroken observational records from 1794. The National Botanic Gardens (1800) and the Ordnance Survey Headquarters in the Phoenix Park 


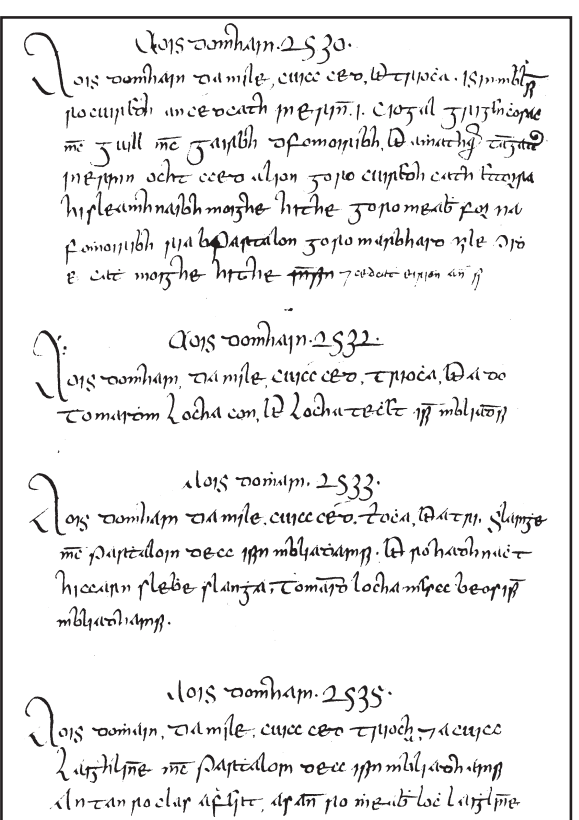

Figure 2. Probably the oldest documentary reference to a weather event in Europe. This ancient Irish manuscript chronicles a storm on Lough Conn in western Ireland, allegedly in 2668 BC. While the veracity of dates from such ancient sources is highly questionable, they are indicative of the historic importance given to climate extremes in Ireland. (Source: Royal Irish Academy.)

(1829), both in Dublin, also provide early sources of data, though, as with all such early records, caution must be exercised due to issues of exposure and instrument quality.

Modern meteorology in Ireland could be considered as commencing in 1860 when the first weather observation was transmitted from Valentia Island in Co. Kerry. Admiral FitzRoy chose Valentia as one of a network of 15 stations throughout Britain and Ireland which would help to improve storm warnings for ships at sea. In Valentia's case, its position servicing the trans-Atlantic cable meant it had a telegraphic link to London. By the early twentieth century, instrument reliability was rapidly improving, and with independence and the establishment of a flying-boat service from the Shannon Estuary to North America, the newly formed Irish Meteorological Service commenced a period of rapid expansion. A synoptic network of around 15 stations formed the mainstay of the observational network. These were manned by trained observers and provided hourly observations. They have in recent years mostly been replaced by in-house developed automatic stations (TUCSON - The Unified Climate and Synoptic Observation Network). Sadly, some longestablished observational parameters have become, as elsewhere, a casualty of this automation. Around 80 climatological stations supplement this network, manned mostly by amateur observers who also
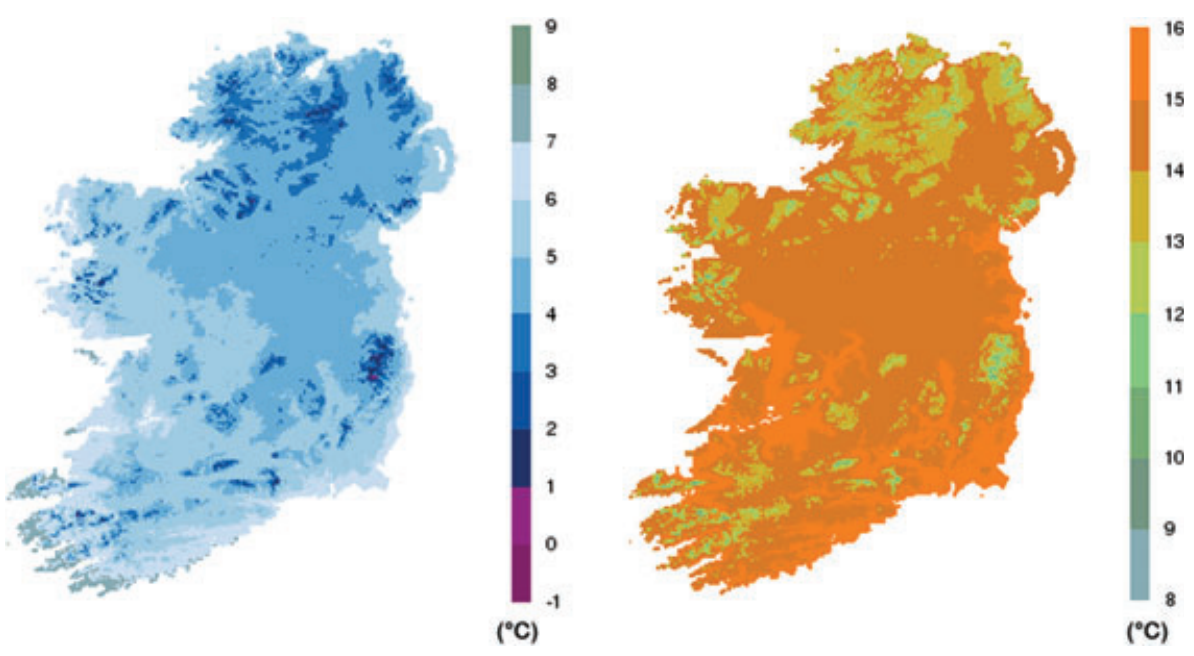

Figure 3. Mean winter and summer temperatures (1981-2010). (Source: Met Eireann, 2012.)

provide daily rainfall data from approximately 400 sites. Lighthouses, oil and gas rigs, ships and buoys further supplement the observational infrastructure. With such a long-established network, issues of exposure, instrument changes and observer consistency inevitably arise, and a programme of data homogenisation has commenced to ensure the integrity of the observational records.

\section{Temperature}

The moderating influence of the North Atlantic Drift provides Ireland with one of the most equable climates in the mid latitudes. This branching and eddy-dominated current is highly variable in speed and direction: it takes around a year to deliver water from Florida to the Kerry coastline at around $10^{\circ} \mathrm{C}$ in February and $16^{\circ} \mathrm{C}$ in August. The temperature contrast in winter of 3-4 degC between offshore sea and onshore land has two significant consequences. First, sensible and latent heat is transferred to frontal systems, thus tending to make them more active in winter in western parts of the island and, aided by the incorporation of tropical maritime air into rapidly-developing wave depressions, this further increases the rainfall yield on the western mountains. Secondly, enhancing this orographic effect even further, the offshore warmth in winter facilitates convection. This is especially common in already unstable flows of polar maritime air from the northwest in the wake of depression passages. Such airflows may be warmed from below by as much as 9 degC as they pass over the main axis of the North Atlantic Drift.

The controlling influence of the Atlantic manifests itself in both seasonal and monthly average temperatures (Figure 3 and Table 1). Throughout the island, the annual temperature does not typically vary by more than $\pm 0.5 \mathrm{deg}$ ( more frequently than once a decade. As with most strongly maritime locations in the northern hemisphere mid latitudes, the coldest month tends to be February, and the warmest August. Table 1 confirms these oceanic influences, with a decrease in equability along a southwest-tonortheast gradient, as well as with distance from the coast. In terms of temperature, the most 'continental' part of the island is probably in south Ulster, in the Cavan/Monaghan/ Tyrone area, where mean minimum temperatures are below $4^{\circ} \mathrm{C}$ from November until mid April. The mean is higher than this throughout the winter along the south and west coasts. By contrast, mean maximum temperatures at Aldergrove, near Belfast, exceed those at Valentia (some $325 \mathrm{~km}$ further south) from May through to September.

Mean January temperatures exceed $7^{\circ} \mathrm{C}$ along the southwest coast, falling to less than $4^{\circ} \mathrm{C}$ in many inland parts of Northern Ireland. While the coast-versus-inland gradient is pronounced in winter, it is less so in summer when a more latitudinal influence is apparent. With a mean July temperature of $16.4^{\circ} \mathrm{C}$, Shannon Airport is almost $2 \mathrm{deg} C$ warmer than the northern tip of the island at Malin Head. Urban heat-island effects have also been measured for cities such as Dublin, and probably account for an enhancement of city temperatures by an average of over a degree during the course of a year (Sweeney, 1987).

Oceanic influences militate against the occurrence of extreme temperatures. The collective national longing for a 'good summer' is seldom realised, though summer 2013 provided a welcome contrast to a sequence of wetter and cooler summers that has characterised recent years. The 'summer of the century' was 1995 when $30.8^{\circ} \mathrm{C}$ was recorded in Kilkenny. This is unremarkable by European standards and indeed during the 1976 summer in the UK 
Table 1

Monthly and annual mean maximum (upper rows) and minimum (lower rows) temperatures ( ${ }^{\circ} \mathrm{C}$ ), 1981-2010.

\begin{tabular}{|c|c|c|c|c|c|c|c|c|c|c|c|c|c|}
\hline Site & Jan & $\mathrm{Feb}$ & Mar & Apr & May & Jun & Jul & Aug & Sep & Oct & Nov & Dec & Year \\
\hline Dublin Casement & 8.0 & 8.2 & 10.2 & 12.4 & 15.2 & 17.9 & 19.8 & 19.5 & 17.1 & 13.6 & 10.2 & 8.3 & 13.4 \\
\hline (81m asl) & 2.1 & 2.0 & 3.3 & 4.1 & 6.6 & 9.4 & 11.5 & 11.3 & 9.5 & 7.0 & 4.2 & 2.4 & 6.1 \\
\hline Belmullet & 8.9 & 9.1 & 10.4 & 12.2 & 14.6 & 16.2 & 17.6 & 17.8 & 16.5 & 13.7 & 11.0 & 9.2 & 13.1 \\
\hline (11m asl) & 3.7 & 3.6 & 4.7 & 5.8 & 7.9 & 10.4 & 12.2 & 12.2 & 10.7 & 8.4 & 6.0 & 4.2 & 7.5 \\
\hline Cork Airport & 8.2 & 8.3 & 9.9 & 11.8 & 14.4 & 17.0 & 18.7 & 18.5 & 16.5 & 13.2 & 10.3 & 8.5 & 12.9 \\
\hline (154m asl) & 3.0 & 3.1 & 4.0 & 4.9 & 7.4 & 10.0 & 11.8 & 11.8 & 10.2 & 7.7 & 5.2 & 3.7 & 6.9 \\
\hline Malin Head & 8.1 & 8.1 & 9.3 & 10.8 & 13.1 & 15.1 & 16.8 & 17.0 & 15.6 & 13.0 & 10.4 & 8.6 & 12.2 \\
\hline (25m asl) & 3.6 & 3.5 & 4.4 & 5.8 & 7.8 & 10.3 & 12.1 & 12.3 & 10.9 & 8.5 & 6.1 & 4.2 & 7.5 \\
\hline Shannon Airport & 8.8 & 9.2 & 11.1 & 13.3 & 16.0 & 18.3 & 19.8 & 19.6 & 17.7 & 14.3 & 11.1 & 9.0 & 14.0 \\
\hline (6m asl) & 3.2 & 3.2 & 4.5 & 5.7 & 8.2 & 10.9 & 12.9 & 12.7 & 10.8 & 8.2 & 5.5 & 3.6 & 7.4 \\
\hline Valentia & 9.8 & 9.8 & 11.0 & 12.5 & 14.9 & 16.7 & 18.1 & 18.2 & 17.0 & 14.3 & 11.8 & 10.3 & 13.7 \\
\hline (12m asl) & 4.7 & 4.6 & 5.4 & 6.3 & 8.4 & 10.8 & 12.7 & 12.6 & 11.2 & 9.0 & 6.8 & 5.3 & 8.2 \\
\hline Aldergrove & 7.1 & 7.5 & 9.5 & 11.9 & 15.0 & 17.4 & 19.0 & 18.6 & 16.4 & 12.9 & 9.5 & 7.4 & 12.7 \\
\hline (81m asl) & 1.7 & 1.6 & 2.9 & 4.3 & 6.8 & 9.7 & 11.7 & 11.4 & 9.5 & 6.9 & 4.0 & 2.1 & 6.1 \\
\hline
\end{tabular}

Table 2

Monthly and annual averages of air frost (days), 1981-2010.

\begin{tabular}{lcccccccccccccc} 
Site & Jan & Feb & Mar & Apr & May & Jun & Jul & Aug & Sep & Oct & Nov & Dec & Year \\
\hline Dublin Casement & 7.5 & 7.7 & 4.6 & 3.4 & 0.8 & 0.0 & 0.0 & 0.0 & 0.0 & 1.3 & 4.3 & 7.6 & 37.2 \\
Belmullet & 4.0 & 3.8 & 1.2 & 0.4 & 0.0 & 0.0 & 0.0 & 0.0 & 0.0 & 0.1 & 1.1 & 3.5 & 14.1 \\
Cork Airport & 4.6 & 4.1 & 1.8 & 1.2 & 0.0 & 0.0 & 0.0 & 0.0 & 0.0 & 0.2 & 1.2 & 3.6 & 16.7 \\
Malin Head & 2.4 & 2.1 & 1.0 & 0.2 & 0.0 & 0.0 & 0.0 & 0.0 & 0.0 & 0.0 & 0.3 & 2.0 & 8.0 \\
Shannon Airport & 5.3 & 5.1 & 2.1 & 0.7 & 0.0 & 0.0 & 0.0 & 0.0 & 0.0 & 0.5 & 2.3 & 4.8 & 20.8 \\
Mullingar & 9.9 & 8.9 & 5.5 & 3.1 & 0.4 & 0.0 & 0.0 & 0.0 & 0.0 & 1.5 & 5.4 & 8.2 & 43.0 \\
Valentia & 2.6 & 3.0 & 1.3 & 0.4 & 0.0 & 0.0 & 0.0 & 0.0 & 0.0 & 0.2 & 0.8 & 2.8 & 11.0 \\
Aldergrove & 8.6 & 8.2 & 5.0 & 2.7 & 0.4 & 0.0 & 0.0 & 0.0 & 0.0 & 0.9 & 3.6 & 7.6 & 37.0
\end{tabular}

- the hottest there since records began maximum temperatures reached $32.2^{\circ} \mathrm{C}$ somewhere in England on 15 consecutive days. The highest maximum in Ireland remains the $33.3^{\circ} \mathrm{C}$ recorded at Kilkenny Castle on 26 June 1887, again unremarkable set against the UK record of over $38^{\circ} \mathrm{C}$ in August 2003.

The extension westwards of the Siberian winter anticyclone is the only force capable of eliminating Atlantic influences from Irish climate, and brings its major instances of extreme cold. Winter 2009/2010 provided the most recent example, when with one of the most negative winter North Atlantic Oscillation index (NAOI) levels on record, Ireland had its coldest winter since 1962/1963. At inland stations, 70-80 ground frosts were experienced, while even Valentia had 62, three times its average winter figure. Although few long-term temperature records were broken, historic lows were closely approached. In many parts of the midlands, for example, minima dipped below $-14^{\circ} \mathrm{C}$, exceptionally low for an island that normally epitomises mild, oceanic winter conditions. Recorded temperatures provide only a sample of the conditions experienced, since in low-lying valley loca- peratures still further. But the extreme lows are notable. Although based on calculations earlier than the 1981-2010 observations, minima at the coast below about $-7^{\circ} \mathrm{C}$ and inland below about $-15.5^{\circ} \mathrm{C}$ are considered to be once-in-a-century occurrences. A reading of $-16.3^{\circ} \mathrm{C}$ on 7 January 2010 at the climatological station of Mount Juliet (Co. Kilkenny) was the lowest recorded in the country since January 1979. In Castlederg (Co. Tyrone), $-18.6^{\circ} \mathrm{C}$ on 23 December 2009 set a new record low for Northern Ireland. The low temperature record for Ireland as a whole for the twentieth century is $-18.8^{\circ} \mathrm{C}$ recorded at Lullymore (Co. Kildare) in January 1979 and the 'all time record' is $-19.1^{\circ} \mathrm{C}$ in January 1881 from Markree Castle (Co. Sligo). However, what was most remarkable about the 2009/2010 severe cold was its occurrence so early in the winter and the coldness of the daytimes. On 21 December the temperature at Ballyhaise (Co. Cavan) never rose above $-9.4^{\circ} \mathrm{C}$, making it the coldest day ever recorded in Ireland.

\section{Frost}

Frost occurs on about 40 days per year at inland locations, but on fewer than 10 days in most coastal areas (Table 2). Occurrences may be greater where ponding of cold air occurs in valleys and hollows, such as along the river valleys of the Barrow, Nore and Suir. The numerous lakes along the course of the River Shannon provide relatively warm surfaces that limit the formation of frost in their vicinity, but the enclosed limestone hollows of areas such as the Burren (Co. Clare) provide ideal locations to trap cold air inflows. Frost hollows do exist too, despite the proximity of the Ocean: reports from the Carran Depression, the largest enclosed limestone hollow in the British Isles, indicate that cattle may have perished overnight during the cold winter of 1947 (Haughton, 1953).

'The Great Frost' which affected Ireland and the rest of Europe between December 1739 and September 1741 resulted in a famine of comparable magnitude to the Great Famine of $1845-1852$; up to $38 \%$ of the population may have perished (Dickson, 1997). The year 1741, during which the famine was at its worst, has entered folk memory as the 'year of the slaughter'.

Frost incidence is notably lower in the 1981-2010 averages than in earlier 30-year periods. The period during which mean daily soil temperatures exceed $6^{\circ} \mathrm{C}$, generally taken as the threshold for grass growth 


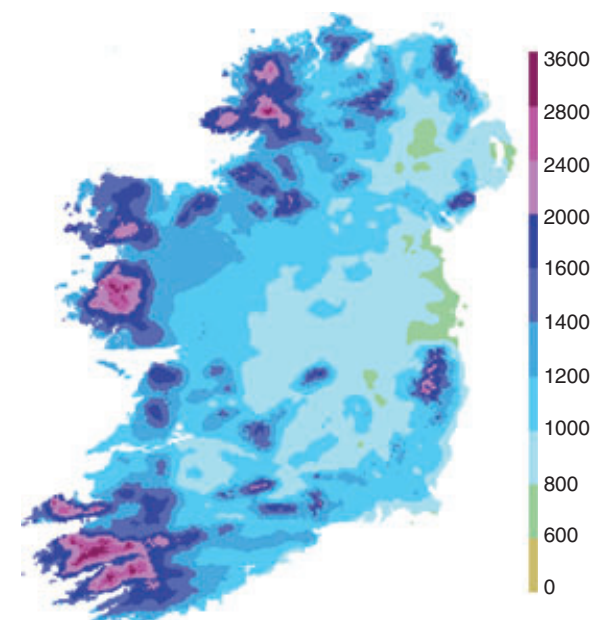

Figure 4. Mean annual precipitation $(\mathrm{mm})$ (1981-2010). (Source: Met Eireann, 2012.)

to commence, has also lengthened, so that the all-year growing season of the southwest and favoured coastal areas has extended some distance inland. Spring diffuses northeastwards from Co. Kerry over a period of about three weeks, giving the southwest an important competitive advantage in the production of early crops and cattle by virtue of its climatic endowment.

\section{Precipitation}

An oceanic location astride the main depression tracks of the northeast Atlantic ensures precipitation will be a central aspect of Ireland's climate. Cyclonic, convective and orographic processes are all active, sometimes simultaneously, though spatial and temporal variability in the mix does occur. The 1981-2010 annual distribution (Figure 4) shows the classic west-to-east decline, with parts of the western mountains receiving over $3000 \mathrm{~mm}$ annually compared to around $750 \mathrm{~mm}$ in sheltered areas along the east coast. Nationally, the average is $1230 \mathrm{~mm}$ (Walsh, 2012). The highest reliable annual

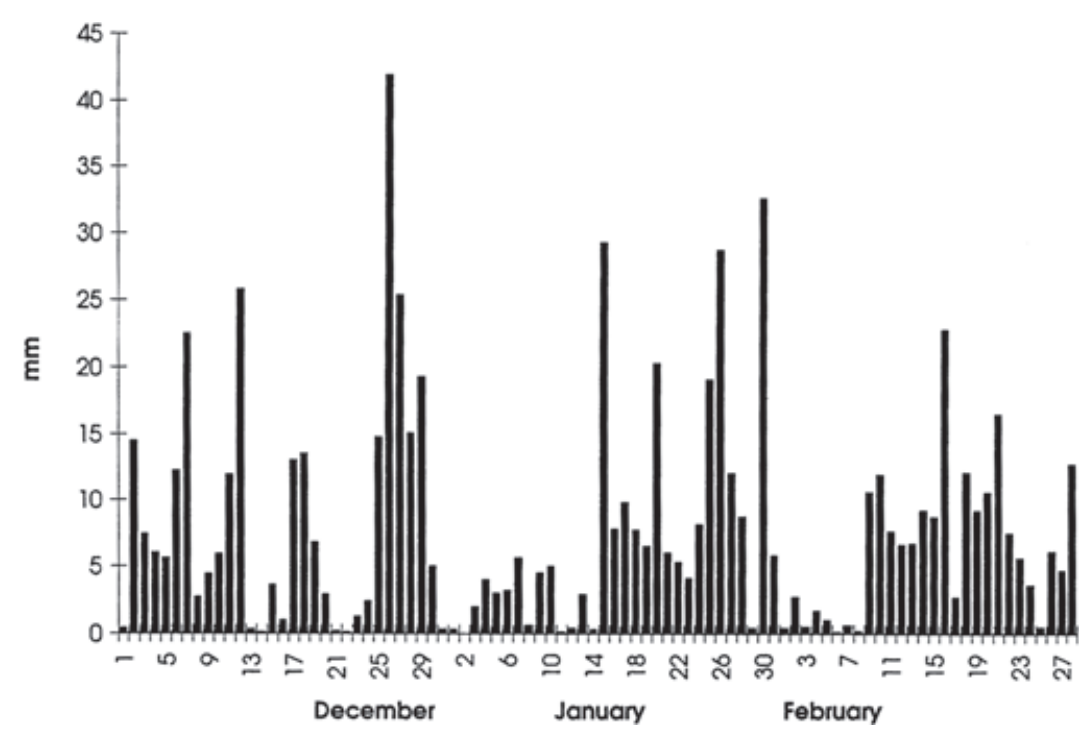

Figure 5. Daily rainfall ( $\mathrm{mm}$ ) at an exposed westerly location (Gort) Winter 1994/1995. in the North Atlantic Oscillation. juxtaposed. total measured is $3965 \mathrm{~mm}$ at Ballaghbeama Gap (Co. Kerry) in 1960. By contrast, the $357 \mathrm{~mm}$ measured at Glasnevin (Dublin) in 1887 is the lowest annual total on record in Ireland. Such spatial contrasts result from the interaction between relief and Atlantic airstreams which produce significant rainshadow effects to the east of the mountains. These are clearly evident east of the Donegal, Mayo and Cork-Kerry mountains, and also exist east of the Wicklow Mountains along the eastern coastal fringe. Perhaps the most remarkable example is the sheltered area of the 'Golden Vale' extending south from the Shannon Estuary. Annual totals of less than $1000 \mathrm{~mm}$ are more typical of the English Midlands than the west coast of Ireland. Protected on almost all sides, except due west, by mountains, this is probably the most sensitive location in Ireland to changes

Orographic enhancement has been suggested by Sumner (1988) to be more complex than simply forced-ascent related, and may involve the mountains acting as heat sources on clear days, thus inducing convective shower activity. Betts (1990) found that, over the Mourne Mountains, orographic enhancement of up to $6 \mathrm{mmh}^{-1}$ occurred on occasion. In some circumstances, this was further complicated by convective instability induced by airstreams being squeezed through the North Channel. Such mechanisms are also likely to be at work elsewhere in the island where particular airstream trajectories and topographic alignments are

Ireland's rainfall is characterised by low intensity and long duration. Outside of a few upland areas, hourly falls of more than $40 \mathrm{~mm}$ have a less than 1-in-a-100-year return period, as do daily falls of over $125 \mathrm{~mm}$ (Fitzgerald, 2007). Despite public perception to the contrary, precipitation is observed only for $6.5 \%$ of the time in eastern parts, a figure comparable to that of

erly and orographic processes may result in substantial additional delivery mechanisms. The Mount Merrion thunderstorm of 11 June 1963 remains the most intense event at sea level with $184.2 \mathrm{~mm}$ being measured in a 24-hour period at this south Dublin location, $75 \mathrm{~mm}$ of which fell in one hour (Morgan, 1971). Dublin's urban heat island may have further enhanced convection on this occasion. In late summer and early autumn Ireland may be on the receiving end of Atlantic hurricanes which have metamorphosed into deep mid-latitude depressions. Ex-hurricane Charley in August 1984 was one such example. Deepening rapidly as it tracked along the south coast and into the Irish Sea, this system delivered an estimated $280 \mathrm{~mm}$ on 25 August in the highest parts locations. The low intensity/high duration rain is observed on 150 days of the year in the east and 225 in western areas. In winters with a high positive NAOI, parts of the west rain on all but a handful of days (Figure 5). Over the course of an average year, slight
temporal differences in rainfall can be detected. A significantly drier period is eviJuly (Table 3), corresponding to a seasonal in the intensity of Atlantic deprescool up to midsummer and warming of the surface is still proceeding, minimising the coast. Indeed, convection over the coastal fringes of the west produces parts in winter, whilst peak activity in ner occurs in the east (Figure 6): thunValentia (mostly in winter), with a similar Dublin (mostly in summer). The comences results in a more seasonal rainfall me on the western half of the island contrast, the more sheltered east exhibits thore 'continental'influences because supplements to its rainfall regime. The wetmonth in over a century of records at what surprising for an island often taken to typify a maritime-controlled climate. Hail west coast; during summer, hail is rarely observed anywhere (on average at most one

Extreme rainfall events tend to have multiple causations, not just frontal passages, of which about 170 occur in an average year. n summer, because of higher temperatures, the moisture-carrying capacity of the west- 
Table 3

Monthly and annual averages of precipitation (mm), 1981-2010.

\begin{tabular}{|lccccccccccccc|}
\hline Site & Jan & Feb & Mar & Apr & May & Jun & Jul & Aug & Sep & Oct & Nov & Dec & Year \\
\hline $\begin{array}{l}\text { Dublin } \\
\text { Casement }\end{array}$ & 63.8 & 48.5 & 50.7 & 51.9 & 59.1 & 62.5 & 54.2 & 72.3 & 60.3 & 81.6 & 73.7 & 75.7 & 754 \\
Belmullet & 134.0 & 97.1 & 99.2 & 72.0 & 70.4 & 72.1 & 79.0 & 102.0 & 102.0 & 146.0 & 134.0 & 137.0 & 1245 \\
Cork & 131.0 & 97.8 & 97.6 & 76.5 & 82.3 & 80.9 & 78.8 & 96.8 & 94.6 & 138.0 & 120.0 & 133.0 & 1228 \\
Airport & & & & & & & & & & & & & \\
Malin Head & 117.0 & 84.8 & 85.9 & 63.1 & 56.9 & 69.1 & 76.8 & 93.2 & 91.8 & 118.0 & 105.0 & 114.0 & 1076 \\
Shannon & 102.0 & 76.2 & 78.7 & 59.2 & 64.8 & 69.8 & 65.9 & 82.0 & 75.6 & 105.0 & 94.1 & 104.0 & 978 \\
Airport & & & & & & & & & & & & & \\
Valentia & 174.0 & 124.0 & 124.0 & 96.7 & 93.5 & 95.3 & 99.0 & 115.0 & 125.0 & 177.0 & 169.0 & 165.0 & 1557 \\
Aldergrove & 80.3 & 57.7 & 67.0 & 58.0 & 57.3 & 61.5 & 71.4 & 83.8 & 75.6 & 89.6 & 79.7 & 79.3 & 861 \\
\hline
\end{tabular}

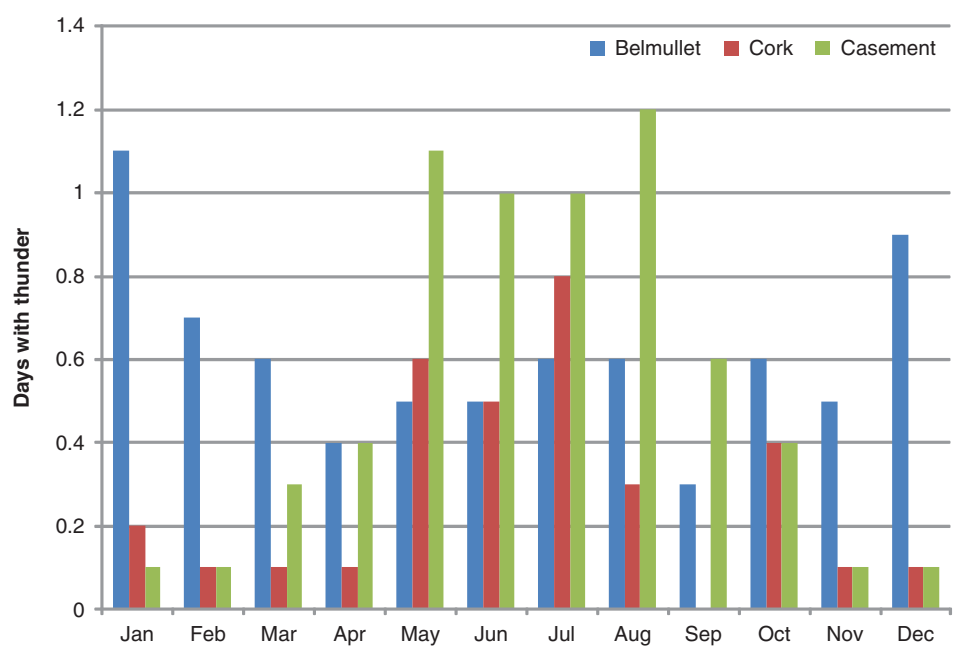

Figure 6. Mean monthly days with thunder 1981-2010.

of the Wicklow Mountains and $200 \mathrm{~mm}$ at sea level close to the east coast (Meteorological Service, 1986). Both of the Liffey's mountainous tributaries, the Dargle and the Dodder, burst their banks, flooding over 400 houses, some to a depth of $2.5 \mathrm{~m}$.

Extreme rainfall in winter tends to occur in the early part of the season, when some of the above influences are still active enough to enhance depression-related rainfall amounts. The 'atmospheric river', a narrow band of concentrated water vapour, which can contain a greater flux of water than the Amazon, occasionally delivers extreme rainfall amounts to the eastern Atlantic fringes (Lavers et al., 2011). Most recently, following on from a very wet summer in Ireland, an 'atmospheric river' became entrained in the westerly circulation from 16 to 20 November 2009, and record-breaking rainfall was recorded. For 4- to 5-day durations, the estimated return periods for some stations exceeded the 500-year computed limit on the return-period model (Walsh, 2010). Inevitably this resulted in Ireland's most serious flood event in living memory in the most affected parts of the west and south with property losses, economic disruption and some fatalities (see Figure S1 on inside front cover). Indeed, the flood events, which were similarly severe in Cumbria, have of specific weather events as threshold elements in turning incremental adaptation to climate change into transformational change via the mechanisms of changing social contracts between civil society and the state (Adger et al., 2012).

Droughts are rare in Ireland, as seldom does the Atlantic relinquish control for long. Measurable rainfall has occurred somewhere in the synoptic network every month since the 1940s. The longest absolute drought was recorded in Limerick from 3 April to 10 May 1938. Notwithstanding this, some memorably dry summers have occurred, most notably the 'summer of the century' in 1995, and to a lesser extent in 2006 when only $89 \mathrm{~mm}$ of rain was recorded at Shannon during the three summer months.

\section{Snowfall}

Substantial snowfalls are rare in Ireland and, given the relative warmth of the ground surface, especially in western parts, snow seldom lingers for more than a day or two. Eastern and northeastern interior locations fare worst, with Aldergrove having over 30 days per year on average with snow falling. Valentia has only 5 such days, and snow lies here on less than a day per year on average; elsewhere it lies on 2-7 days in an average year. A snow depth of more than $10 \mathrm{~cm}$ is a once in a 6-18 year event at most inland locations, and was a non-event at most coastal sites over the past half century (Murphy, 2012). The record cold winter of 2010/2011 brought a snow accumulation of $27 \mathrm{~cm}$ at Dublin's Casement Aerodrome, making it one of the heaviest three snow events recorded there.

\section{Synoptic origins of Irish precipitation}

Marked spatial variations in precipitation have for long been known to be linked with particular airflow trajectories (Sweeney, 1985; Sweeney and O'Hare, 1992). Matching daily yields to the Lamb circulation types confirms that it is cyclonic, southerly and westerly airflows that are the most productive (Figure 7). Cyclonic circulations produce a relatively even spatial distribution, giving on average around $4 \mathrm{~mm}$ with a slight reduction in the interior of Ireland where oceanic water vapour will be slightly less abundant. An area of instability around the North Channel may relate to the convergence processes discussed earlier. While westerly circulations yield similar amounts overall, a marked spatial imbalance between northwestern and eastern coastal areas is apparent. Typically, up to three times as much precipitation occurs in Connaught and west Ulster than along the Leinster coast. Southerly airflows, especially in autumn when the sea is at its warmest, are the highest yielding circulations overall, with a pronounced southwest-northeast gradient. To some extent, these west-east gradients are reversed with easterly circulations, though the longer fetch across the Celtic Sea means the south coast rather than the east coast is the main beneficiary. Cork, for example, gets similar rainfall overall from easterly and westerly airflows.

Year-to-year and seasonal changes in precipitation are clearly highly dependent on changes in the frequency of particular airflow types, in particular the vigour of the westerlies relative to more continental airflows. Unsurprisingly, therefore, a significant correlation exists between winter precipitation in Ireland and the winter NAOI (Sweeney et al., 2002). Current uncertainty in global and regional climate models as regards future Irish precipitation will therefore not be resolved until these can effectively handle frequency changes, both natural- and anthropogenically-forced, in key circulation types.

\section{Sunshine}

As already discussed, convection in summer is weaker on the cooler coastal margins than further inland, especially where onshore circulations predominate. Accordingly, more bright sunshine tends to be recorded along 

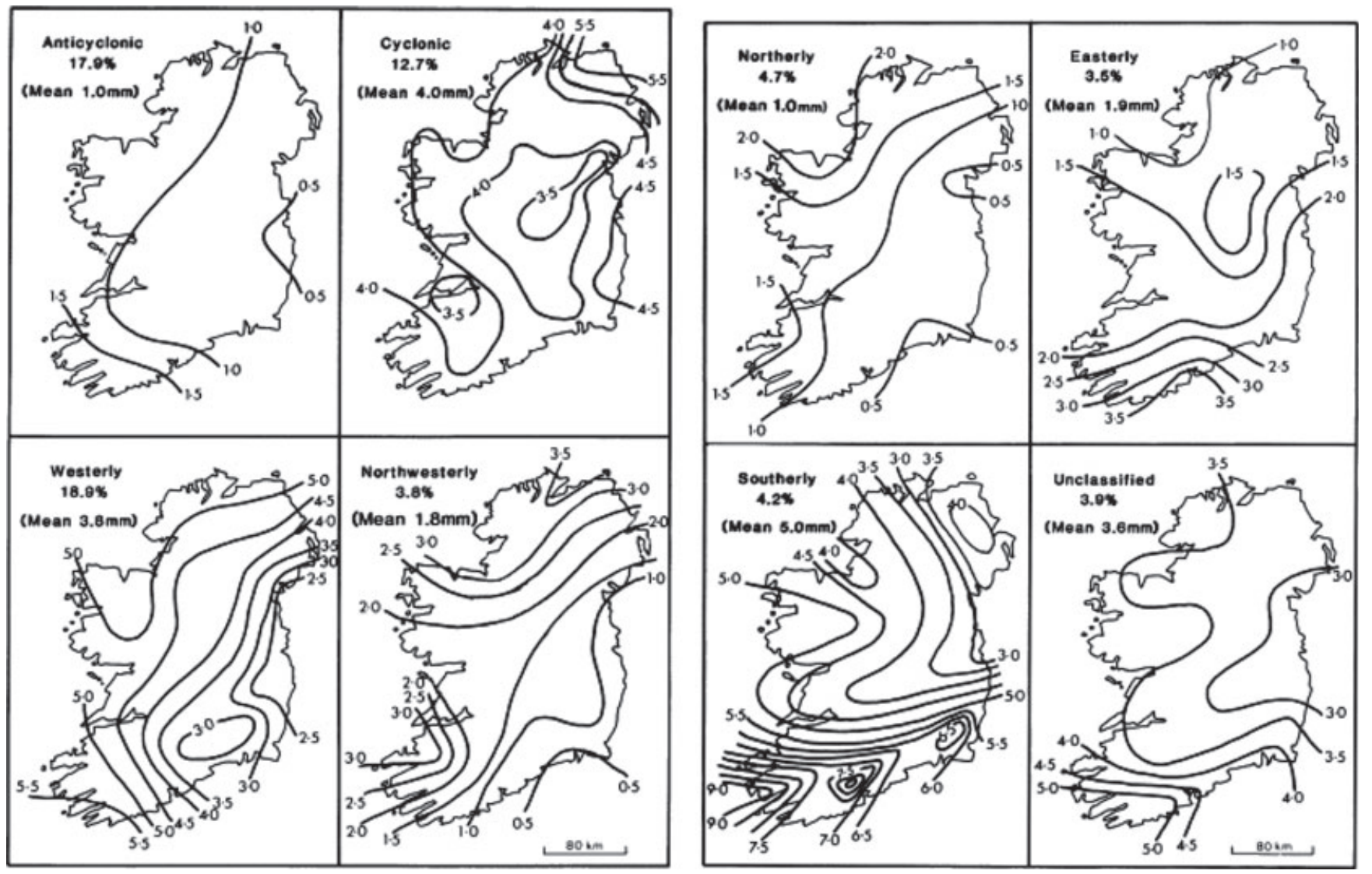

Figure 7. Daily rainfall receipt in Ireland with different Lamb Circulation Types.

coastal margins than in the interior of the island. In the rain shadows east of the mountains, significant enhancement of sunshine hours occurs, especially in the extreme southeast. Monthly averages for bright sunshine (Table 4) indicate that most parts of the island enjoy a daily average of 3-4 hours. December is the dullest month with only one hour of sunshine per day on average in the north and two hours in the extreme south. May and June are the sunniest months, reflecting the greater frequency of drier airflows in late spring/early summer. The sheltered southeastern corner of Wexford enjoys a quite remarkable average of approximately seven hours of daily sunshine at this time, similar to the amounts received in coastal Kent and East Anglia. Overall, though, Ireland is a cloudy island (skies are completely cloudcovered about one-third of the time) and, considering some of the upland sunshine recorders in Northern Ireland, it appears that fewer than $25 \%$ of the annual potential sunshine hours are realised (Betts, 1990).

\section{Fog}

As with the other phenomena, fog frequency largely responds to land-sea temperature influences. In summer, it occurs on the coastal margins at typically three times their winter equivalent, a reflection of the relatively cool ocean's ability to generate sea fog which encroaches onshore. In winter, fog frequencies peak at the relatively cold inland stations.

\section{Wind}

The dominance of wind directions from the south and west is apparent at all stations (Figure 8). In high summer a more pronounced westerly component exists as the northward displacement of the Azores High tends to sharpen the south-to-north pressure gradient over Ireland at this time. From late winter to early summer the tendency for more anticyclonic weather provides the main occurrences of northerlies and easterlies - the latter are especially common in February as a result of blocking over Scandinavia. Some stations clearly exhibit the effects of shelter from nearby high ground, most clearly shown in the case of Dublin and Shannon Airports from southerlies. In Northern Ireland, funnelling along the Foyle Valley and through the Lough Erne lowland has also been noted (Betts, 1982). Shelter and friction with a land surface also explains the marked reduction in mean annual windspeed from $7 \mathrm{~ms}^{-1}$ along the northwest coast to less than $4 \mathrm{~ms}^{-1}$ in the south midlands, as well as explaining

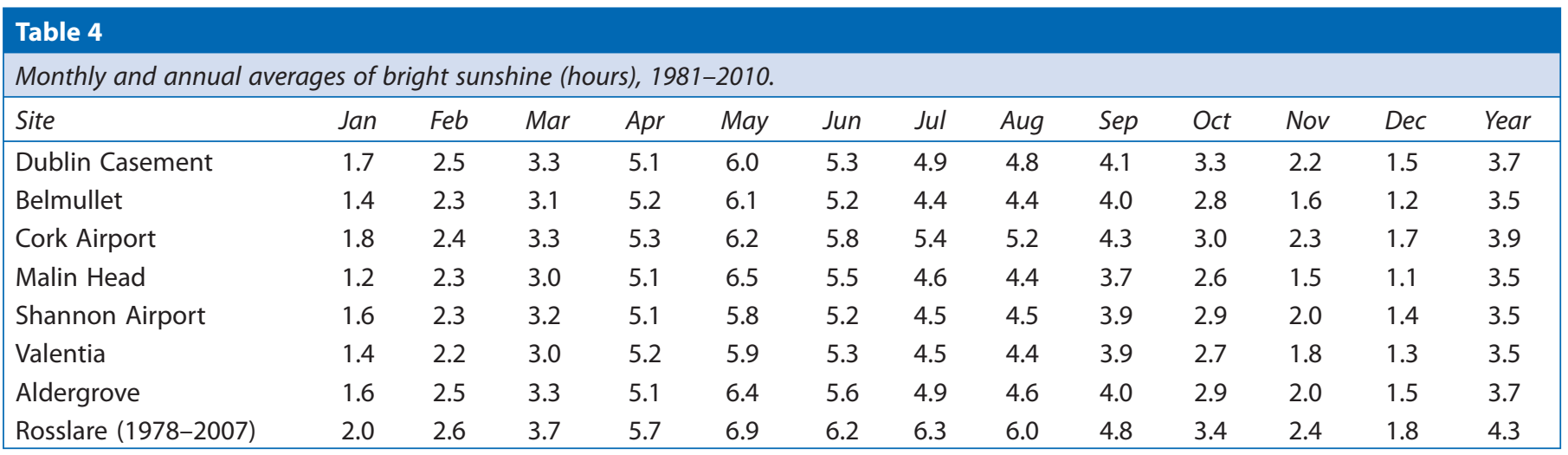


Table 5

Average number of gale days per month for the period 1981-2010 and highest gusts observed.

\begin{tabular}{|lrrrlllllllllll}
\hline Site & Jan & Feb & Mar & Apr & May & Jun & Jul & Aug & Sep & Oct & Nov & Dec & Year & Maximum gust (knots) \\
\hline Malin Head & 11.8 & 10.3 & 8.7 & 3.6 & 2.1 & 1.0 & 0.7 & 1.1 & 3.0 & 6.5 & 8.0 & 8.5 & 65.3 & 96 \\
Kilkenny & 0.5 & 0.4 & 0.2 & 0 & 0 & 0 & 0 & 0 & 0 & 0.1 & 0.1 & 0.6 & 1.9 & 58 \\
Cork Airport & 2.3 & 1.8 & 1.3 & 0.3 & 0.3 & 0 & 0.1 & 0.2 & 0.3 & 1.0 & 1.2 & 1.9 & 10.8 & 66 \\
Dublin (Casement) & 4.5 & 3.2 & 2.1 & 0.6 & 0.4 & 0.1 & 0.1 & 0.2 & 0.3 & 1.2 & 1.9 & 3.5 & 18.1 & 82 \\
Valentia & 2.4 & 1.5 & 0.9 & 0.2 & 0.3 & 0 & 0 & 0.1 & 0.1 & 0.8 & 1.0 & 1.5 & 8.8 & 88 \\
Belmullet & 7.0 & 4.8 & 3.1 & 1.4 & 0.9 & 0.2 & 0.2 & 0.4 & 1.5 & 2.6 & 3.1 & 4.4 & 29.6 & 94 \\
Shannon Airport & 1.7 & 0.9 & 0.8 & 0.3 & 0.2 & 0.1 & 0 & 0.1 & 0.1 & 0.6 & 0.7 & 1.2 & 6.7 & 83 \\
\hline
\end{tabular}

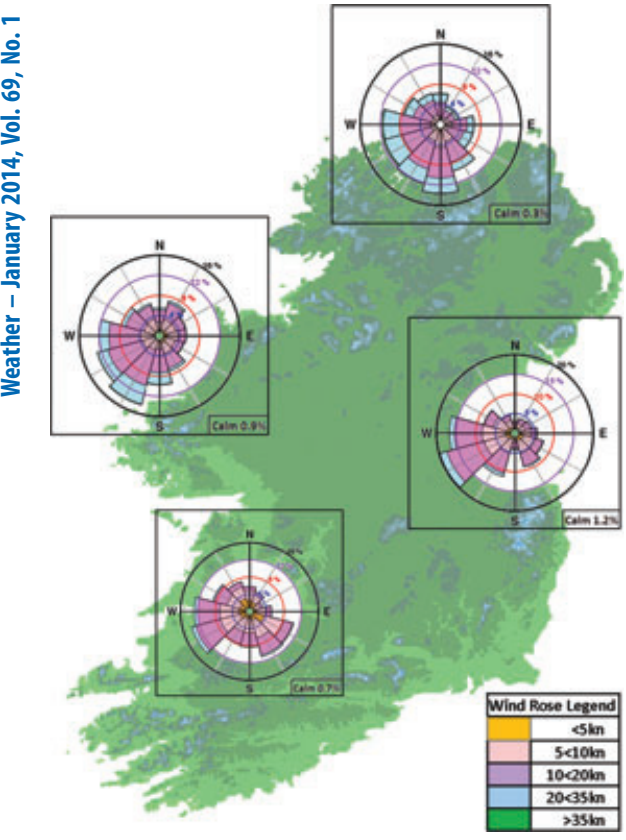

Figure 8. Wind Roses (1981-2010).

the decrease in annual average gale days from over 65 on the north Ulster coast to less than 2 in inland Leinster (Table 5). This variation in wind climate is thus comparable to that between the Western Isles and Lowland England, and further emphasises the climate contrasts existing between the western perimeter and eastern interior of Ireland.

The highest winds are normally observed around the Ulster coast where proximity to explosive deepening of Atlantic depressions is greatest. Frequently the culprit is a rapidly deepening secondary depression which may wreak havoc over a few hours, for example on 11 January 1974 when such a feature, eventually with surface pressure of $936 \mathrm{mbar}$, was responsible for a gust of $108 \mathrm{kn}$ at Kilkeel (Co. Down): this remains the record for the island as a whole. However, the 'Night of the Big Wind' in 1839 remains the most potent reminder of what damage-potential exists. This depression probably had a central pressure as low as $918 \mathrm{mbar}$, though only a rudimentary network of instrumental observations was then available (Shields and Fitzgerald, 1989). The storm cost 250-300 lives, damaged $20-25 \%$ of the houses in 26 Dublin City, levelled several thousand trees, drenched locations $15 \mathrm{~km}$ inland in brine (with anecdotal accounts of herring and other fish being deposited $6 \mathrm{~km}$ inland) and wrecked 42 ships. The 'Night of the Big Wind' came after the County Meath native, Sir Francis Beaufort, devised his scale of wind force, which has proven so universally popular over the past two centuries. The event was also believed to have been influential in encouraging Rev. John Romney Robinson of Armagh Observatory to develop his cup anemometer and install one of his original instruments on the East Pier of Dun Laoghaire harbour in Dublin Bay, where it still spins today.

A need to better quantify storm hazards exists, particularly in light of the long record of variability in their frequency and intensity. A rudimentary storm chronology for the Dublin region constructed using documentary and instrumental record indicates a period of marked storm activity in the early eighteenth century which corresponds to the later stages of the Little Ice Age in Ireland. Instrumental records, though also imperfect, suggest that the twentieth century had a number of stormy intervals, particularly in the 1920s, 1960s and late 1980s/ early 1990s (Sweeney, 2000). An expectation of an increase in storm activity in the vicinity of Ireland exists for the medium term as the oceans surrounding the island warm. In the longer term, though, a decline in the vigour of the westerly circulation can also be anticipated and at this point confidence in projecting future changes in Ireland's wind climatology is low.

\section{Conclusions}

Ireland's long tradition of documenting and observing its weather confirms the dominant characteristics as moist and equable, a function of its island location amid the 'disturbed westerlies' of the mid-latitude atmospheric circulation and the North Atlantic Drift of the surrounding ocean. It is, in many respects, the epitome of a maritime climate. Yet while the Atlantic dominates Irish climate, it acts on a distinctive topography characterised by coastal uplands and an interior plain. Many parameters thus show a contrast between the exposed maritime fringe and sheltered interior, although subtle variants of this occur. The climatic mosaic which results, therefore, reflects a complex interplay between latitudinal, topographic and oceanic influences.

The drivers of dramatic day-to-day weather changes are the air-mass changes generated by temporal and spatial shifts in the semi-permanent pressure systems of the Icelandic Low, the Azores High and the winter Siberian High. The temporary dominance of one or other of these influences ensures a surprising variability in weather types. Frequency changes of the air trajectories concerned over longer time periods is what brings longer-term changes in climate, especially if compounded by changes in ocean temperature.

As a mid-latitude country, Ireland's temperature can be expected to change along similar lines to the global average; the 1981-2010 period shows mean temperatures about $0.5 \mathrm{deg} C$ higher than for 19611990 (Walsh, 2012). Much of this is linked to summer minima and winter maxima, and Ireland has been spared the extreme heatwave conditions that have affected many parts of continental Europe in recent years. An unambiguous rainfall change signal is not yet apparent. However, as the ocean around the island warms, Ireland, no less than elsewhere, will need to put in place the necessary adaptive measures to enable it to continue to achieve maximum benefit from its climatic endowment.

\section{Acknowledgement}

The author wishes to thank Met Eireann for permission to use data and figures relating to the 1981-2010 averages and my colleague Ronan Foley for assistance with mapping.

\section{References}

Adger WN, Quinn T, Lorenzoni I, Murphy C, Sweeney J. 2012. Changing social contracts in climate change adaptation. Nat. Clim. Change. doi:10.1038/ NCLIMATE1751.

Betts N. 1982. Climate, in Northern Ireland: Environment and Resources. Cruickshank J, Wilcock D (eds). Queen's University of 
Belfast and University of Ulster: Belfast.

Betts N. 1990. A Synoptic Climatology of Precipitation in Northern Ireland. Queen's University of Belfast: Belfast.

Dickson D. 1997. Arctic Ireland. White Row Press: Dublin.

Dixon FE. 1969. Some Irish Meteorologists. Irish Astronomical Journal 9(4): 113-19.

Fitzgerald D. 2007. Estimation of Point Rainfall Frequencies, Technical Note 61. Met Éireann: Dublin.

Haughton J. 1953. Land use in the Carran polje. Irish Geogr. 2: 225-226.

Lavers DA, Allan RP, Wood EF, Villarini G, Brayshaw DJ, Wade AJ. 2011. Winter floods in Britain are connected to atmospheric rivers. Geophys. Res. Lett. 38 L23803. doi:10.1029/2011GL049783.

Meteorological Service. 1986. August Storms, Monthly Weather Bulletin
(Supplement to August 1986). Met

Éireann: Dublin.

Morgan WA. 1971. Rainfall in the

Dublinarea on 11th June 1963, Internal Memorandum No. IM/72/71. Met Éireann: Dublin.

Murphy A. 2012. Snowfall in Ireland. Met Éireann: Dublin, 12 pp.

Shields L, Fitzgerald D. 1989. The Night of the Big Wind in Ireland 6-7 January 1839. Irish Geogr. 22: 31-43.

Sumner G. 1988. Precipitation: Process and Analysis. Wiley: Chichester, UK, 455 pp.

Sweeney J. 1985. The changing synoptic climatology of Irish rainfall. Trans. Inst. Br. Geogr. 10: 467-480.

Sweeney J. 1987. The urban heat island of Dublin City. Irish Geogr. 20(1): 1-10

Sweeney J. 2000. A three-century storm climatology for Dublin 1715-2000. Irish Geogr. 33: 1-14.
Sweeney J, Donnelly A, McElwain L, Jones M. 2002. Climate Change: Indicators for Ireland. Environmental Protection Agency, Johnstown Castle: Wexford, Ireland, $71 \mathrm{pp}$.

Sweeney J, O'Hare G. 1992. Geographical variations in precipitation yields and circulation types in Britain and Ireland. Trans. Inst. Br. Geogr. 17: 448-463.

Walsh S. 2010. Report on Rainfall of November 2009, Climatological Note 10. Met Éireann: Dublin.

Walsh S. 2012. A Summary of Climate Averages for Ireland 1981-2010, Climatological Note 14. Met Éireann: Dublin.

\section{Correspondence to: John Sweeney}

John.Sweeney@nuim.ie

(c) 2014 Royal Meteorological Society

DOI: 10.1002/wea.2230
Readers are encouraged to submit letters for possible publication. Letters can be submitted either electronically through the system used for articles, by email attachment to weather@wiley.com or by post, as shown on the Contents page. The Letters Editor reserves the right to edit any letter.

\section{Large hail in supercell storms}

A recent article by Clark and Webb (2013) describes a persistent supercell storm that produced large hail over a long swath in the English Midlands. I was interested to read that, at two stages during the lifetime of this storm, the hail size diminished shortly after the merger with new storms approaching from the right flank. I suggest below that this may not have been mere coincidence.

An important stage in the growth of large hail is the entry of hailstone embryos (small precipitation particles) into an intense updraught. In a supercell storm the embryos get carried around the perimeter of the intense updraught core, which is often characterised by a vault-shaped region of weak radar echo. Upper-level observations capable of showing a weak-echo vault are not presented in the article by Clark and Webb (2013) but M. R. Clark (pers. comm.) confirms that one did exist in the storm they studied.

A vault in general is characterised by large concentrations of supercooled cloud droplets in the absence of larger particles: the cloud droplets by themselves are too small to be seen easily by most weather radars. The vault is important because it is a symptom of inefficiency in the conversion of cloud water to precipitation. Paradoxically it is this very inefficiency that encourages the growth of large hail by minimising the effects of competition among the embryos for the available supercooled cloud droplets (Browning and Foote, 1976). Those embryos that find their way to the very edge of the vault compete 'unfairly' by being the first to encounter the undepleted cloud water in the vault and these are the embryos that may grow into large hail. However, if large numbers of embryos in the form of raindrops from a neighbouring storm are ingested by the inflow into the core of the main updraught (thereby obliterating the vault) then these might compete with one another for the available cloud water to the extent that none would be able to grow into large hailstones.
The entry of embryos from a neighbouring storm into the updraught core (vault) of a supercell storm was observed by Browning (1965) but one cannot be sure in that case, or indeed in the case described by Clark and Webb (2013), that sufficient embryos would have entered the updraught core to suppress the generation of large hail (small numbers of additional embryos entering the vault could actually increase the number of large hailstones). Detailed cloud modelling studies might shed further light on this issue.

\section{References}

Clark MR, Webb JDC. 2013. A severe hailstorm across the English Midlands on 28 June 2012. Weather 68(11): 284-291.

Browning KA. 1965. Some inferences about the updraft within a severe local storm. J. Atmos. Sci. 22: 669-677.

Browning KA, Foote GB. 1976. Airflow and hail growth in supercell storms and some implications for hail suppression. Q. J. R. Meteorol. Soc. 102: 499-533.

Keith Browning Ambleside, Cumbria DOI: 10.1002/wea.2264 